\title{
The Ethanol Extract of Marine Sponge Aaptos suberitoides Suppress Cell Viability, Cell Proliferation and Cell Migration in HER2-Positive Breast Cancer Cell Line
}

\author{
Muhammad Hasan Bashari1 ${ }^{1,2}$, Fadli Zaky Arsydinilhuda ${ }^{3}$, Re Septian Ilhamsyah ${ }^{3}$, \\ Annisa Dewi Nugrahani ${ }^{3}$, Ryzkianty Annis Nurdin ${ }^{3}$, Ajeng Kartikasari ${ }^{4}$, Fathul \\ Huda $^{1}$, Maman Abdurahman ${ }^{5}$, Tenny Putri ${ }^{6}$, Nurul Qomarilla ${ }^{6}$, Harold Atmaja ${ }^{6}$, \\ Ikhwan Resmala Sudji ${ }^{7}$, Beginer Subhan ${ }^{8}$, Hermin Aminah Usman', Yunisa \\ Pamela $^{1}$, Eko Fuji Ariyanto ${ }^{1}$, Edy Meiyanto ${ }^{10}$
}

\begin{abstract}
Objective: This study aimed to investigate the cytotoxicity, anti-proliferation and anti-migration effect of the ethanol extract of Aaptos suberitoides on trastuzumab-resistant HER2+ breast cancer cell line. Methods: Aaptos suberitoides was collected from Tinjil Island, Banten, Indonesia, and was processed with maceration and ethanol extraction. HCC-1954 cells were treated with the ethanol extract and then followed by 3- [4, 5-dimethylthiazol-2-yl] -2.5 diphenyl tetrazolium bromide (MTT) assay to assess cytotoxicity, clonogenic assay and three-dimensional (3D) spheroid assay to evaluate anti-proliferative effect in two-dimensional and 3D model, respectively, and wound healing assay to determine anti-cell migration effect. Four parametric regression was used to analyse the $\mathrm{IC}_{50}$. Results: This study revealed that the ethanol extract of Aaptos suberitoides suppressed cell viability in correlation with cell death induction. $\mathrm{The} \mathrm{IC}_{50}$ values of the ethanol extract of Aaptos suberitoides using MTT assay and clonogenic assay were $12.0 \mathrm{ppm}$ and $4.36 \mathrm{ppm}$, respectively. The extract demonstrated an inhibition effect on spheroid growth. In low concentration, the extract of Aaptos suberitoides inhibited cell migration. Furthermore, MS analysis showed that the most abundant compounds in this extract has molecular weight $\mathrm{m} / \mathrm{z} 229.81[\mathrm{M}+\mathrm{H}]+$. Conclusion: This study revealed that the ethanol extract of Aaptos suberitoides demonstrates cytotoxicity, anti-proliferation and anti-migration effect as well as inhibition effect on three-dimensional spheroid growth in trastuzumab-resistant HER2+ breast cancer cell line.
\end{abstract}

Keywords: Aaptos suberitoides- anti-cancer- HER2+ breast cancer cell line- marine sponge

Asian Pac J Cancer Prev, 22, Anticancer Activity of Natural Compounds: HOW's on Methods and Reports Suppl, 25-32

\section{Introduction}

Breast cancer $(\mathrm{BC})$ is the most common cancer and the leading cause of cancer death among women across the world (Forouzanfar et al., 2016). A common diagnostic modality to classify BC is using immunohistochemistry (IHC) status according to the existence of estrogen receptor (ER), progesterone receptor (PR) and human epidermal growth factor 2 (HER2). The three main classifications are ER/PR+, HER2-(hormone positive);
HER2 + regardless of its ER/PR status (HER2 positive); and ER/PR-, HER2- (triple-negative) (Sinn and Kreipe, 2013; Hon et al., 2016; Gnant et al., 2017). About 30\% cases of BC were HER2+ BC, a subtype that has a lower survival rate, higher relapse rate, and earlier age of onset than the other subtypes of BC (Ahmed et al., 2015). Trastuzumab is the main therapeutic modalities, but some patients do not respond well to this drug due to resistance. The emergence of trastuzumab-resistant HER2+ BC and its high tendency to develop brain metastasis raise the 
urgency to discover alternative therapeutic strategies for this type of BC (Verma et al., 2012).

Aaptos suberitoides marine sponges are abounded in West Pacific Ocean especially in Indonesia, Singapore, and Vietnam (Halanych, 2004). They are sessile organisms having the ability to produce high secondary metabolites and to synthesize a variety of organic compounds such as polyketide, alkaloid, peptide, and terpene (Nurhayati et al., 2018). Aaptamine, a compound discovered in Aaptos suberitoides, has several bioactive properties such as cytotoxicity, anti-cancer, anti-virus, anti-microbe, anti-parasite, and anti-inflammation (Newman and Cragg, 2004; Fattorusso et al., 2012; Ouyang et al., 2012; van Soest et al., 2012; Yunovilsa Putra and Jaswir, 2014). Aaptamine has been proven to have anti-cancer properties in human osteosarcoma cell line, leukemia P388 cell line, KB16 cell line, Ehrlich tumor cell, cervical cancer cell line HeLa and A549 cell line (Aoki et al., 2006; Larghi et al., 2008; Nurhayati et al., 2018).

This study aimed to investigate cytotoxicity, anti-migration, anti-proliferation, and growth inhibitory effect of Aaptos suberitoides in HER2+ BC cell line. Recent data showed the close relevance of 3-dimensional (3D) spheroid cell culture methods in comparison with in vivo outcome (Friedrich et al., 2009; Vinci et al., 2012; Hsiao et al., 2012; Breslin et al., 2013; Thoma et al., 2014; Breslin and O'Driscoll, 2016). This method of cell culture has never been conducted in previous research with marine sponge Aaptos suberitoides. Therefore, we used $3 \mathrm{D}$ spheroid growth assay to evaluate the sponge effect in HER2+ BC growth inhibition. In addition, to investigate the cytotoxic effect we used 3- [4, 5-dimethylthiazol-2yl] -2.5 diphenyl tetrazolium bromide (MTT) assay and clonogenic assay. The effect of sponge in HER2+BC cell's migration ability was evaluated using wound healing assay.

\section{Materials and Methods}

\section{Materials}

Doxorubicin and paclitaxel were gifted from pharmacy Dr. Hasan Sadikin Hospital, Bandung, Indonesia. Other materials and instruments used were ethanol 96\%, culture medium RPMI1640 (Gibco, cat.no. 11875085, USA), DMEM-F12 (Gibco, cat.no. 11320033, USA), Fetal Bovine Serum (FBS)(Gibco, cat.no. 26140079, USA), Penicillin/Streptomycin (Sigma, cat.no. P4333, USA), Phosphate Buffered Saline (PBS) (Gibco, cat. no. 10010001, USA), Trypsin (Gibco, cat.no. 15050057, USA), MTT assay (3- [4, 5-dimethylthiazol-2-yl] -2.5 diphenyl tetrazolium bromide cat No. M2128, SigmaAldrich, USA), dimethyl sulfoxide (DMSO) (Sigma, cat No. D8418, USA), cell culture incubator (Thermo Scientific model 3429, USA, 2014), inverted microscope (Olympus CK40, Japan), microscope camera (C-mount camera, China), ImageJ software (v1.51, National Institute of Health, USA), Microsoft Excel software (v.16.30, 2016), GraphPad Prism software (v7.0a, 2016).

\section{Sample preparation}

Marine sponge Aaptos suberitoides was collected from the coast around Tinjil Island, Banten, Indonesia by diving about 20 meters below sea levels. The fresh sponges were chopped and macerated in $96 \%$ ethanol for 2-3 days followed by filtration using filter paper. The suspension was evaporated using Rotary Evaporator to obtain a concentrated paste extract. The ethanol extract was stored in $4^{\circ} \mathrm{C}$ chiller. For stock solution, the extract was dissolved in $100 \%$ DMSO to have a $40.000 \mathrm{ppm}$ concentration of the ethanol extract of Aaptos suberitoides. For further experiments, this stock solution was diluted with a complete culture medium as required concentrations.

\section{Mass spectrometry analysis}

To analyze the molecular weight of compounds in the ethanol extract of Aaptos suberitoides, we used WATERS Acquity UPLC MS/MS H-Class (Waters, USA). Sample was diluted in methanol followed by direct infusion to the TQD-MS/MS system. For the full scanning, compounds were scanned from molecular weight $\mathrm{m} / \mathrm{z}$ 100-1,000 (with a protonated molecular ion $[\mathrm{M}+\mathrm{H}]+$ ). In addition, the most abundance finding molecule was further analyzed for daughter scan using MS/MS daughter scan setting.

\section{Cell culture conditions}

The HCC-1954 cells were used as trastuzumab resistance HER2+ BC cell model. The cells were gifted by Dr. Wiemann (National Center for Tumor Diseases, Heidelberg, Germany). Cells were cultured using RPMI 1,640 supplemented with $10 \%$ FBS dan $1 \%$ penicillin/ streptomycin in a standard incubator that maintained in with $37^{\circ} \mathrm{C}$ temperature and $5 \% \mathrm{CO} 2$. All experiments were conducted at Cell Culture and Cytogenetic Laboratory, Faculty of Medicine, Universitas Padjadjaran.

\section{MTT Assay}

The cell viability and cytotoxic effect Aaptos suberitoides was evaluated using the MTT assay. Briefly, the cells were seeded in 96 well plates, incubated for 24 hours, and followed by treatment with a serial concentrations of the ethanol extract of Aaptos suberitoides for 72 hours. The cells were then treated by MTT reagents for 4 hours and the reaction was stopped using DMSO. Then, the plates were shaken to dilute the crystal formazan before reading the absorbance using a plate reader with a wavelength of $550 \mathrm{~nm}$. The percentage of cell death was calculated based on the absorbance value of the sample, control, and blank. The experiment was conducted in 3 repetitions with a serial concentration in triplicate.

\section{Morphological Observation}

To evaluate the morphological changes of HCC-1954 cells, the cells were seeded on cover slip of 24 well-plate followed by treatment with serial concentrations of the ethanol extract of Aaptos suberiotides as well as paclitaxel as a positive control. Cells were captured 72 hours after treatment under a light microscope connected with a camera at 200x magnification and observed for morphological characteristics of cell death.

\section{Clonogenic Assay}

To evaluate the inhibitory effect of ethanol extract of 
Aaptos suberiotides, clonogenic assay was conducted in HCC-1954 cells by calculating the percentage of colony formation area. HCC-1954 cells were seeded in 12 well plates with 2,500 cells/well. As soon as the cells attached to the bottom of the well, cells were exposed to the ethanol extract of Aaptos suberitoides with 0 ppm concentration (control), 1, 2.5, 5, 10, and 25 ppm prior to 72 hours of incubation. Then, the media were replaced with the new one and the cells were grown for a week. On the last day, medium was discarded, and colonies were fixed with methanol for 5 minutes followed by staining with crystal violet for 3 minutes and rinsing. Clonogenic plates were photographed for further analysis using ImageJ software (National Institute of Health, USA) based on the area of assessment and color threshold in each well. Data were presented as the mean of $\%$ colony formation inhibition ([1- (mean of area/control) x 100]) of triplication with three repetitions.

\section{Spheroid growth assay}

The monolayer HCC-1954 cells were trypsinized and resuspended with DMEM-F12 supplemented with penicillin $100 \mathrm{U} / \mathrm{ml}$, streptomycin $100 \mu \mathrm{g} / \mathrm{ml}$, and FBS $10 \%$. 7,000 cells in $200 \mu \mathrm{l}$ of cell suspension were seeded onto the agarose-coated well followed by centrifuging the plate at 1,000 rpm for 5 minutes and then incubated for 96 hours. Next, the Ferret's diameter spheroids were measured under an inverted microscope. Spheroids with a diameter of less than $360 \mu \mathrm{m}$ were excluded from the experiments.

Spheroids were grouped into negative control, positive control, and serial concentration of Aaptos suberitoides extract. The negative control was spheroids in DMEM-F12 containing DMSO 1\%. The positive control was spheroids in Doxorubicin $0,5 \mu \mathrm{g} / \mathrm{ml}$. The 5 treatment groups were spheroids each treated with $0.5 \mu \mathrm{g} /$ $\mathrm{ml}, 5 \mu \mathrm{g} / \mathrm{ml}, 10 \mu \mathrm{g} / \mathrm{ml}, 20 \mu \mathrm{g} / \mathrm{ml}$, and $40 \mu \mathrm{g} / \mathrm{ml}$ ethanol extract of Aaptos suberitoides. Spheroids were treated at 96-hours after cell seeding. They were observed under an inverted microscope connected to a camera. Photographs of the spheroid were captured with the lens focused on the approximately middle depth of the spheroid at day $0,4^{\text {th }}, 8^{\text {th }}$, and $11^{\text {th }}$ after treatment. Spheroids growth was measured by measuring their Feret's diameter using ImageJ software.

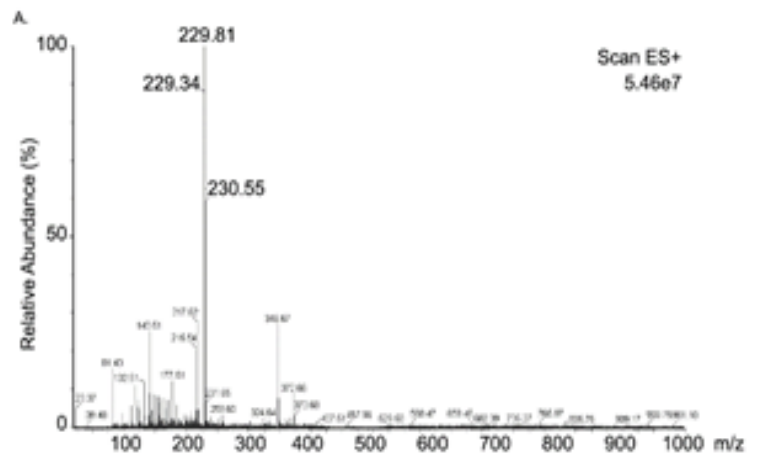

Wound Healing Assay

To evaluate the inhibitory effect of Aaptos suberitoides on migration cells of HCC-1954, the wound healing assay method was conducted in trastuzumab resistance HCC-1954 cells. Marking lines were made with a scalpel under each of the plates before the cells were seeded and incubated for 24 hours. After monolayer was formed, cells were perpendicularly scratched by the tip of $200 \mu \mathrm{L}$ pipette crossed the marking line. The old medium was discarded gently. The plate was tilted and washed with PBS to discard cell debris then finally replaced with a complete culture medium. Cells were treated with ethanol extract of Aaptos suberitoides with 0 ppm, 1 ppm, 2.5 ppm, and $5 \mathrm{ppm}$ concentration. Cells were incubated at $37^{\circ} \mathrm{C}$ temperature and $5 \% \mathrm{CO}_{2}$.

The gap formed was periodically captured at $0,24,48$, 72 hours. The photos were processed by ImageJ software to measure the gap area. Data were presented as the mean of $\%$ of gap closure ((gap area 0 - gap area $n) /($ gap area 0)) of triplication with three repetitions.

\section{Statistical Analysis}

To evaluate anti-proliferation activity, spheroid growth, and the inhibitory effect of migration cells, data was analyzed with one-way ANOVA followed by Post Hoc Dunnett's using GraphPad Prism 7 and Statistical Product and Service Solutions (SPSS) ver. 22. Statistical analysis considered as significant if $\mathrm{P}<0.05$. The evaluation of the IC50 of cytotoxicity and anti-proliferation were analyzed with four-parametric logistic regression using SigmaPlot ver. 12 .

\section{Results}

The ethanol extract of Aaptos suberiotides contains predominant compounds with molecular mass 229ES+ data showed that the most abundant molecular weight of molecule in the ethanol extract of Aaptos suberitoides was $\mathrm{m} / \mathrm{z} 229.81$ (with a protonated molecular ion $[\mathrm{M}+\mathrm{H}]+$ ) (Figure 1A). This compound would be fragmented to $\mathrm{m} / \mathrm{z}$ 214.25 and 196.21 (Figure 1B).

The ethanol extract of Aaptos suberiotides induces cell death in HCC-1954 cells

Experiments were started with an evaluation of the cytotoxic activity of the ethanol extract of

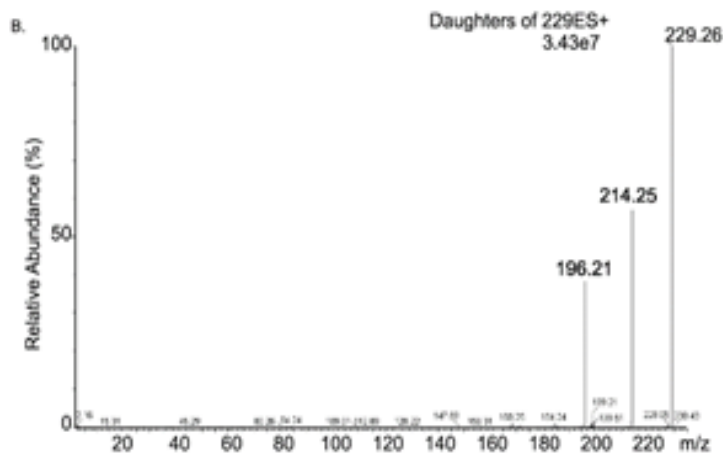

Figure 1. Chromatogram of Mass Spectrometry of Extract of Aaptos Suberitoides. (A) Full scan mass, (B) Daughters of $229 \mathrm{ES}+$. 

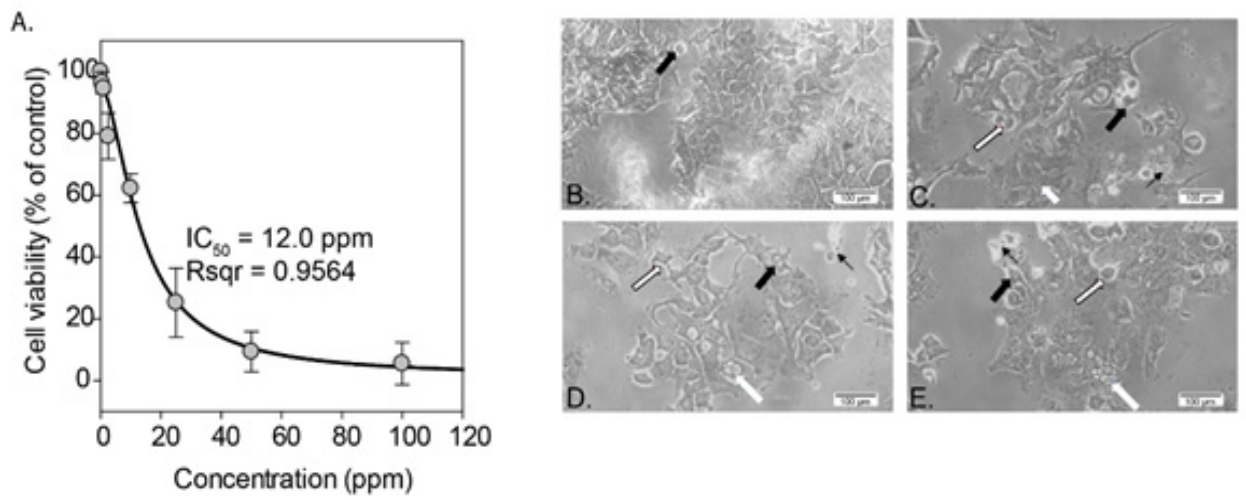

Figure 2. Cell Viability Curve and Microscopic Appearance of HCC-1954 Upon Treatment of Extract of Aaptos Suberitoides. (A) The extract of Aaptos suberitoides suppress percentage of cell viability. The picture showing the microscopic appearance of trastuzumab-resistant HER2+ HCC-1954 cells of untreated (negative control) (B) and treated with extract of Aaptos suberitoides with the following concentrations: $10 \mathrm{ppm}$ (C), $20 \mathrm{ppm}$ (D), and paclitaxel $5 \mathrm{nM}$ (positive control) (E). (magnification 200x). Cells shrinkage and rounded (black tick arrows), the formation of apoptotic bodies (black arrows), and pyknosis (black outlined white arrows), vacuole formation (white arrows).

Aaptos suberiotides in trastuzumab-resistant HER2enriched BC HCC-1954 cells. Data showed that this extract decreases cell viability in a dose-dependent manner (Figure 2A). The $\mathrm{IC}_{50}$ value was $12.0 \mathrm{ppm}$ and $\mathrm{R}$ square was 0.9564 (Figure $2 \mathrm{~A}$ ).

We then observed the microscopic appearance of HCC-1954 cells upon the treatment of the ethanol extract of Aaptos suberiotides. The photograph (Figure 2C and D) shows that the extract induced cells' morphological changes including cell shrinkage, rounded cells, apoptotic bodies as well as vacuole formation and pyknosis, indicating that this extract triggered cell death in trastuzumab-resistant HER2-enriched breast cancer cell line refer to apoptotic process (Degterev and Yuan, 2008). These morphologies are also observed upon treatment of conventional chemotherapy, paclitaxel (Figure 2E).

The ethanol extract of Aaptos suberiotides inhibits cell proliferation in $2 \mathrm{D}$ and $3 \mathrm{D}$ model of HCC1954 cells

We evaluated the anti-proliferative activity of the ethanol extract of Aaptos suberiotides in trastuzumab-resistant HER2-enriched BC HCC-1954 cells using clonogenic assay and spheroid growth assay. Data showed that increasing the concentration of the ethanol extract of Aaptos suberiotides was followed by a reduction in colony formation after a week of incubation (Figure 3A). Quantification of the anti-proliferative effect was performed by measuring the average of colony formation area which had been exposed with the ethanol extract of Aaptos suberiotides that was converted into percentage after comparing them with control. The colony area was quantified using ImageJ. The dose curve is shown in Figure 3B. Similar to cytotoxicity data, the anti-proliferative effect of the extract shows a dose-dependent manner (Figure 3B). The $\mathrm{IC}_{50}$ value was $4.0 \mathrm{ppm}$.

Recent studies showed that 3D spheroid culture models provided a more suitable microenvironment for tumor growth (Friedrich et al., 2009; Vinci et al., 2012; Hsiao et al., 2012; Breslin et al., 2013; Thoma et al., 2014; Antoni et al., 2015; Breslin and O'Driscoll, 2016). Proliferation, necrosis, apoptosis, and shedding occurred dynamically in a different zone of the spheroid. The degree of cell proliferation in the spheroid is reflected by its volume growth. One important component of volume is a diameter that can be measured easily (Lund-Johansen et al., 1991). Therefore, we used a 3D spheroid model to evaluate the activity of the ethanol extract of Aaptos suberitoides.

Spheroids of HCC-1954 cells were treated ethanol
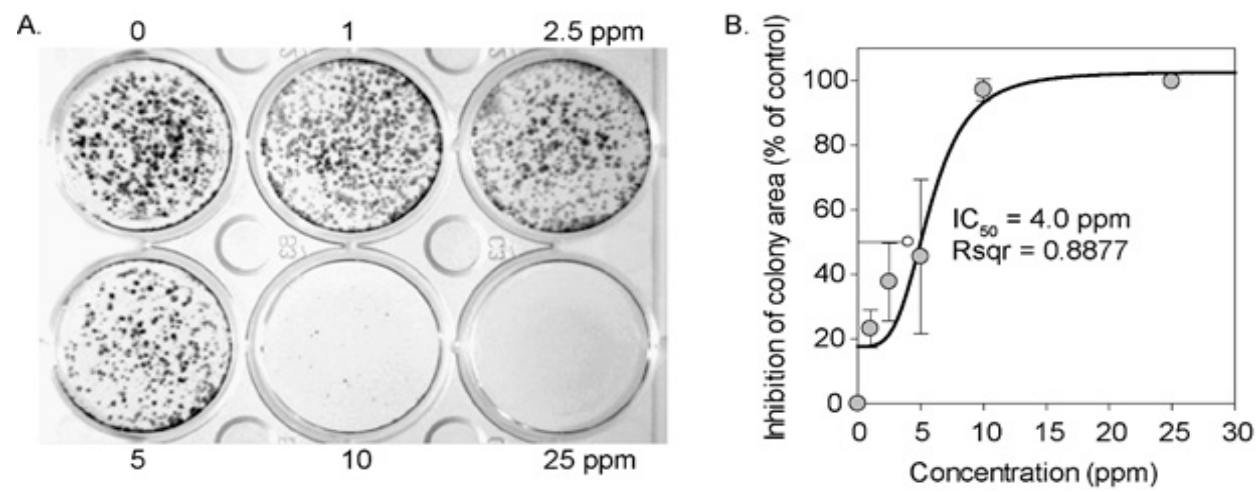

Figure 3. The Ethanol Extract of Aaptos Suberitoides Inhibited the Colony Formation of Trastuzumab-Resistant HCC1954 Cells. (A) Increasing the concentration of the ethanol extract of Aaptos suberitoides was followed by a reduction in colony formation. (B) The curve of Aaptos suberitoides' dosage towards the inhibition of trastuzumab-resistant HCC-1954 
A.

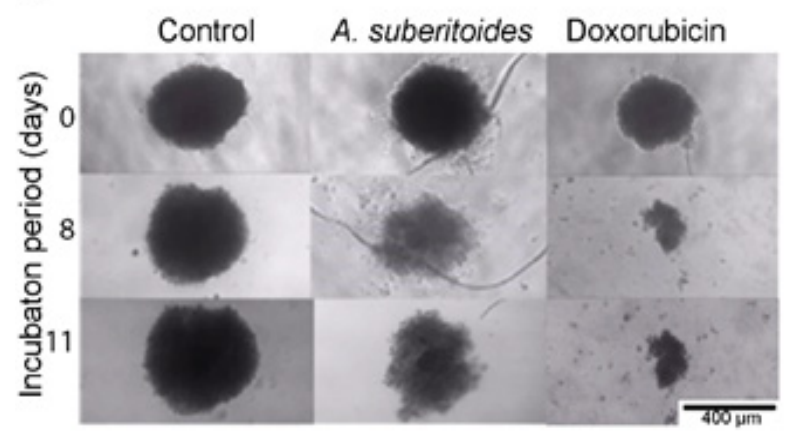

B.

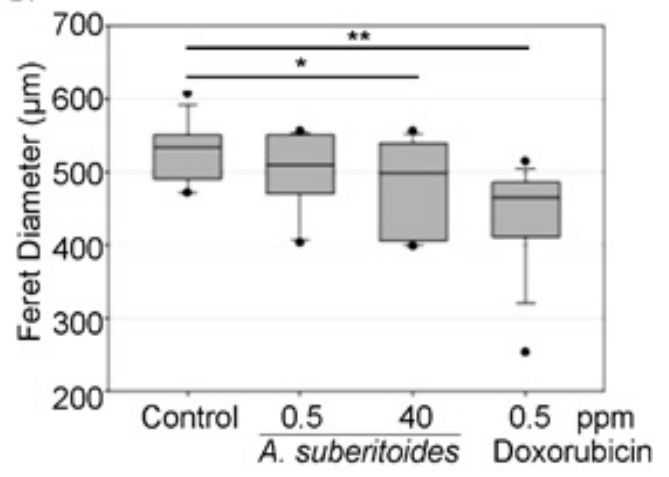

Figure 4. The Ethanol Extract of Aaptos suberitoides Inhibits Spheroid Growth. Spheroid growth were depleted upon treatment of $40 \mathrm{ppm}$ ethanol extract of Aaptos suberitoides and $0.5 \mathrm{ppm}$ doxorubicin than on control group within 11 days (A). The mean of spheroid diameter of the ethanol extract of Aaptos suberitoides, and doxorubicin on day 11th were smaller than the control group, ${ }^{*} \mathrm{p}<0.05,{ }^{*} \mathrm{p}<0.0001$, respectively.

extract of Aaptos suberitoides for 11 days. There was an enlargement of spheroids in the negative control (no treatment) indicating the growth of spheroid. In contrast, the ethanol extract of Aaptos suberitoides led to a loss of spheroid mass followed by spheroid destruction (Figure 4A). Such a condition was also clearly observed following the treatment of $0.5 \mathrm{ppm}$ doxorubicin (positive control). The ethanol extract of Aaptos suberitoides demonstrates inhibition of spheroid growth.

We measured the Ferret's diameter of spheroids of each group at day 0,4 days, 8 days, and 11 days after treatment then we subtracted the value with the spheroid's initial Ferret's diameter at day 0 so that we obtained Ferret's diameter difference that represents spheroid's growth rate. There was not any statistically significant difference between groups at days 0 and 4 after treatment. On day 8 after treatment, the Ferret's diameter difference of spheroids upon treatment of the ethanol extract of Aaptos suberitoides was statistically lower than the negative control group. P-value of the difference between the negative control group and the groups treated with Aaptos suberitoides with the concentration of $40 \mathrm{ppm}, 20 \mathrm{ppm}$, and $10 \mathrm{ppm}$ were $0.001,0.015$ and 0.018 , respectively.

We also compared Ferret's diameter of the ethanol extract of Aaptos suberitoides group with doxorubicin, a commonly used chemotherapeutic drug for BC. By 0.5 ppm concentration, the doxorubicin showed significantly smaller spheroid's ferret diameter than control on day 8 th $(p=0.0001)$ and 11 th $(p=0.0001)$. At the same concentration, the ethanol extract of Aaptos suberitoides still showed a larger diameter compared to the doxorubicin group. Nevertheless, this data suggested a higher cell spheroid's growth rate in the negative control group than the ethanol extract of Aaptos suberitoides group.

\section{The ethanol extract of Aaptos suberiotides inhibits cell migration in HCC-1954 cells}

Finally, we evaluated the effect of the ethanol extract of Aaptos suberitoides on cell migration in HCC-1954 cells. Data were collected in triplication with three repetitions that consist of control and test groups. Treatment groups were treated with a low concentration of the ethanol extract of Aaptos suberitoides by $1 \mathrm{ppm}, 2.5 \mathrm{ppm}$, and $5 \mathrm{ppm}$ concentration. Using the low concentration was to avoid a cytotoxicity bias on cell migration properties. Figure 5 showed that the gap in the control group at $72^{\text {nd }}$ hours was completely closed. The gap remained on the treatment groups at $72^{\text {nd }}$ hours. Indicating the ethanol extract of Aaptos suberitoides marine sponge inhibits the migration of trastuzumab resistance HER2+ BC HCC-1954 cells to
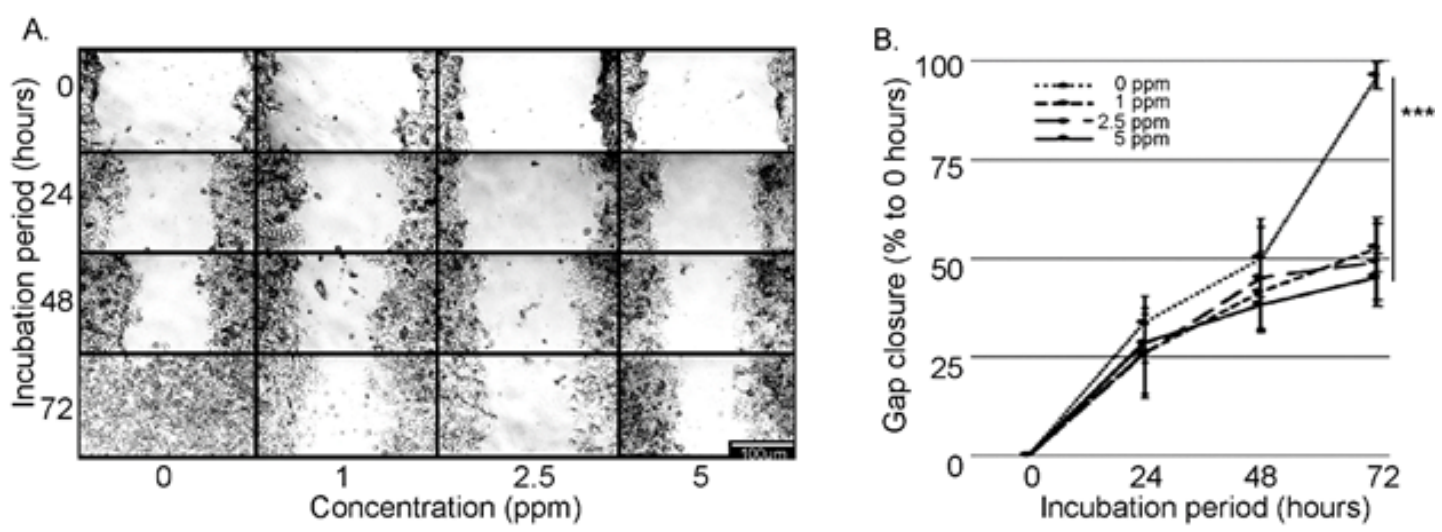

Figure 5. Inhibition of Gap Closure upon Treatment of the Ethanol Extract of Aaptos suberitoides. (A) The gaps of the ethanol extract of Aaptos suberitoides remained open at 72 hours. (B) All treated groups were significantly different from the control group. $* * *=p<0.001$. 
close the gap.

Data were transformed into \% of gap closure. The mean of $\%$ of gap closure at $72 \mathrm{nd}$ hours on the control negative group, the ethanol extract of Aaptos suberitoides concentration $1 \mathrm{ppm}, 2.5 \mathrm{ppm}, 5 \mathrm{ppm}$ were $96.25 \%$, 70\%, $49.03 \%$, and $45.23 \%$, respectively. Gap closure $\%$ was analyzed using one-way analysis of variance (ANOVA) method. The result showed that data were significantly different at $72^{\text {nd }}$ hours $(\mathrm{p}<0.0001)$. The post hoc Dunnett's multiple comparison test showed that the treatment group of $1 \mathrm{ppm}, 2.5 \mathrm{ppm}$, and $5 \mathrm{ppm}$ concentration were significantly different to control group $(p<0.001)$ (Figure $5 B)$.

\section{Discussion}

Pathogenesis of HER $2+$ BC comprises many molecular pathways that lead to cell survival, uncontrolled cell proliferation, and migration. Lower level of protein $21(\mathrm{p} 21)$, a cyclin-dependent kinase inhibitor (CDKI), and Activator protein 1 (AP-1) in HER2+ BC was proposed to be responsible for cell's survival and proliferation, while the high tendency for metastasis in HER2 + BC was associated with modulation of nuclear factor kappa-light-chain-enhancer of activated B cells (NF-kB) (Dyshlovoy et al., 2014; Kumar et al., 2015). Moreover, HER2 enriched BC is characterized by HER2 overexpression caused by HER 2 gene amplification, resulting in induce cell proliferation via MPAK/PI3K pathway (Iqbal and Iqbal, 2014) and other effects increase anti-apoptotic protein Mcl-1 production (Bashari et al., 2016).

Myeloid cell leukemia-1 (Mcl-1) is a Bcl-2 family protein that regulates apoptosis and promoting cell survival by interfering at the cascade of Cytochrome C release from mitochondria (Michels et al., 2005). The previous study demonstrated the existence of Mcl-1-dependent survival pathways in HER2-positive $\mathrm{BC}$ cells. Mcl-1 forms a protein complex with HER2 at the mitochondrial membrane and stabilizes HER2 by inhibiting its ubiquitination and degradation by the Ubiquitin-Proteasome System (UPS) (Michels et al., 2005; Bashari et al., 2016). Non-proteasomal degradation of Mcl-1 by caspase-induced Mcl-1 cleavage occurs at two highly conserved sites, Asp127 and Asp157 in the PEST domain (Michels et al., 2005; Fan et al., 2014) The two C-terminal Mcl-1-cleaved products, Mcl-1128-350 and Mcl- 1158-350, have lost the N-terminal BH4 domain and are structurally similar to Bax in result converts Mcl-1 to a proapoptotic protein (Fan et al., 2014). The study showed that the generation of Mcl-1128-350 was associated with trigger pro-apoptotic c-Jun upregulation and AP-1 transcriptional activity (Fan et al., 2014).

Aaptamine, an alkaloid contained in marine sponge Aaptos suberitoides, was known to enhance p21 expression in human osteosarcoma cell line and modulate the transcription factors of AP- 1 and NF- $\mathrm{kB}$ in murine JB6 Cl41 cells (Aoki et al., 2006; Dyshlovoy et al., 2014). Such a discovery opened an opportunity for Aaptos suberitoides extract to be a novel therapeutic candidate for HER2+ BC. Alkaloids, and aaptamine included, are known to have proteasome inhibitory activity (Tsukamoto et al., 2010; Afifi, 2017). It suggests that aaptamine has potency on inducing cancer cell death via triggering apoptosis.

Aaptos suberitoides has been studied for years. The ethanol extract of Aaptos suberitoides has been shown potential anti-cancer activity in different cancer entities, including acting as antiproliferation, proapoptosis, and as proteasome inhibitor (Tsukamoto et al., 2010; Dyshlovoy et al., 2014; Wu et al., 2016; Calcabrini et al., 2017; Sa'adah et al., 2017; Rajivgandhi et al., 2019). Beside aaptamine, previous study showed that the extract of Aaptos suberitoides also contains alkaloid compounds including demethyl aaptamine, and isoaaptamine (Dyshlovoy et al., 2014). Aaptamine was firstly identified by Nakamura et al in 1982 and 1987 at range $\mathrm{m} / \mathrm{z} 228.0885$ and $\mathrm{m} / \mathrm{z} 230,1064$ (Nakamura et al., 1982, 1987). Another study showed this compound was identified at $\mathrm{m} / \mathrm{z} 229.0971[\mathrm{M}+\mathrm{H}]+(\mathrm{Calcul}$ et al., 2003). Here we also found a prominent compound in the ethanol extract of Aaptos suberitoides at 229.81 (with a protonated molecular ion $[\mathrm{M}+\mathrm{H}]+$ ) indicating that this extract contained aaptamine (Figure 1).

This was the first study in HER2-enriched BC cells for evaluating cytotoxic activity of the ethanol extract of Aaptos suberitoides. Our data showed that the ethanol extract of Aaptos suberitoides collected from Tinjil Island suppressed cells viability and triggered cell death on trastuzumab-resistant HER2 enriched breast cancer cell line (Figure 2). The IC50 was $12 \mathrm{ppm}$ indicating that it has high cytotoxic activity. The American National Cancer Institute (NCI) guidelines set the limit of activity for crude extracts $50 \%$ inhibition $\left(\mathrm{IC}_{50}\right)$ of the proliferation of less than $30 \mathrm{ppm}$ in 72 hours incubation. Moreover, a crude extract with $\mathrm{IC}_{50}$ less than $20 \mathrm{ppm}$ is considered strong cytotoxic (Vijayarathna and Sasidharan, 2012).

In this study, the ethanol extract of Aaptos suberitoides demonstrated the inhibitory effect of colony formation and spheroid growth in HER2+ resistant-trastuzumab breast carcinoma HCC 1954 cells (Figure 2 and 3). Alkaloid aaptamine inhibits the ubiquitin enzyme formation therefore it inhibits proteasomal degradation (Tsukamoto et al., 2010). The p53 activity will increase to suppress the rate of cell proliferation in $\mathrm{S}$ phase and $\mathrm{M}$ phase of the cell cycle. Therefore, Aaptos suberitoides sponge extract is able to play an important role as an anti-proliferation agent (Calcabrini et al., 2017). Previous study showed that aaptamine, an alkaloid contained in marine sponge had anti-cancer effects on several cancer cell lines (Aoki et al., 2006; Larghi et al., 2008; Nurhayati et al., 2018) presumably by its potential ability to activate CDKI p 21 (Aoki et al., 2006).

Similar data was also demonstrated by other studies. Anti-proliferative effect of the ethanol extract of Aaptos suberitoides was found in $\mathrm{HR}+\mathrm{BC}$ cell line T47D (Nurhayati et al., 2018). The Aaptos suberitoides was taken from Pecaron bay, East Java, Indonesia also demonstrated cytotoxic effect on HT29 (colon cancer), Casky (cervical cancer), and T47D cell line (Abdillah et al., 2013). Aaptamine from Aaptos suberitoides, taken from Carita, West Java, Indonesia, arrested the cell cycle of human osteosarcoma MG63 cells (Aoki et al., 2006). All previously used culture method was standard monolayer 
culture method. In addition, our data showed that the ethanol extract of Aaptos suberitoides inhibits spheroid growth using a 3D spheroid culture method. This method allows cells to grow in an environment that mimics in vivo conditions and has close relevance with in vivo outcome (Friedrich et al., 2009; Vinci et al., 2012; Hsiao et al., 2012; Breslin et al., 2013; Thoma et al., 2014; Breslin and O'Driscoll, 2016).

Furthermore, the ability of carcinoma cells to migrate is one of the crucial steps in the process of metastasis. The migration process requires multiple receptors and protein signaling so that cells can be detached and alter the movement of the actin cytoskeleton (Kumar et al., 2015). Transformation of $\mathrm{BC}$ epithelial cells into mesenchymal cells is essential for the migration process. This process is referred to as the Epithelial to Mesenchymal Transition (EMT). The EMT process is characterized by a "cadherin transition" i.e. a decrease in the expression of E-cadherin and an increase in N-cadherin (Wu et al., 2016). Nuclear Factor Kappa B (NF-kB) is a transcription factor that controls TWIST1, SLUG, and SIP1 promoter regions so that the expression of E-cadherin decreases and N-cadherin, MMP-2, MMP-9, and MMP-11 increase (Smith et al., 2014; Pires et al., 2017; Ukaji et al., 2017).

Degradation of the stromal and basal membranes is an important stage before the carcinoma cells migrate. In breast carcinoma, MMP-2 and MMP-9 are a class of gelatinase enzymes associated with tumor invasion and metastasis due to the degradation of type IV collagen in the basement membrane. MMP-9 expression is associated with malignancy, metastases, and poor prognosis (Vizoso et al., 2007; Yousef et al., 2014). The expression MMP-9 is high in triple-negative BC and HER2 + BC (Yousef et al., 2014). MMP-11 is a group of stromalysin enzymes associated with tumor growth and development (Vizoso et al., 2007). In addition, $\mathrm{N}$-cadherin and Cadherin- 11 are non-epithelial cadherins that can suppress the expression of E-cadherin in order to reduce the adhesion of BC. $\mathrm{N}$-cadherin and Cadherin-11 are dominant factors to increase motility and invasion ability (Nieman et al., 1999).

Aaptamine is an alkaloid compound that can inhibit the activation of NF-kB (Dyshlovoy et al., 2014). NF-kB inhibition can induce decrease transcription-EMT factors in the form of increased expression of E-cadherin and decreased expression of N-cadherin, MMP-2, MMP-9, and MMP-11, thus reducing the percentage of Gap Closure, motility, and malignancy of BC (Smith et al., 2014; Pires et al., 2017; Ukaji et al., 2017).

Although we were using some simple methods for evaluating the activities of the ethanol of extract Aaptos suberitoides in HCC-1954 cells, we found some promising data. The ongoing study conducts to further identify the exact molecular mechanisms of Aaptos suberitoides in HER2+ BC cells.

In conclusion, the ethanol of extract Aaptos suberitoides has potent cytotoxic activity in trastuzumab resistance HER2+ BC HCC-1954 cells. It also inhibits cell proliferation in both $2 \mathrm{D}$ and $3 \mathrm{D}$ spheroid model. Moreover, it inhibits cell migration in HER2+ BC HCC1954 cells. Therefore, these data prove that ethanol extract of Aaptos suberitoides is a potential candidate for the source of novel drugs for trastuzumab-resistance HER2+ $\mathrm{BC}$ therapy.

\section{Acknowledgments}

We thank PT Perhutani, Center for Primate Studies LPPM-IPB (PSSP LPPM-IPB)) Pulau Tinjil and Mr. Agus Erdina who supported for collecting samples in Tinjil Island; Mrs. Pratiwi, Apt. from Dr. Hasan Sadikin Hospital, Bandung, Indonesia for supporting this study.

\section{Funding Statement}

This OCEAN project is supported by Competence Research Grant from Universitas Padjadjaran for MHB (no.2476/UN6.C/LT/2019) and a research grant (3670/UN6.C/LT/2019) by the Ministry of Research, Technology, and Higher Education of the Republic of Indonesia.

\section{Statement conflict of interest}

No potential conflict of interest was reported by the authors.

\section{References}

Abdillah S, Nurhayati APD, Nurhatika S, et al. (2013). Cytotoxic and antioxidant activities of marine sponge diversity at Pecaron Bay Pasir Putih Situbondo East Java, Indonesia. J Pharm Res, 6, 685-9.

Afifi AH (2017). The Development of New Anticancer Agents, Which inhibit the Ubiquitin-Proteasome system from Marine Organisms. CU Theses, pp 1-16.

Ahmed S, Sami A, Xiang J (2015). HER2-directed therapy: current treatment options for HER2-positive breast cancer. Breast Cancer, 22, 101-16.

Antoni D, Burckel H, Josset E, Noel G (2015). Three-dimensional cell culture: A Breakthrough in Vivo. Int J Mol Sci, 16, $5517-27$.

Aoki S, Kong D, Suna H, et al (2006). Aaptamine, a spongean alkaloid, activates p21 promoter in a p53-independent manner. Biochem Biophys Res Commun, 342, 101-6.

Bashari MH, Fan F, Vallet S, et al (2016). Mcl-1 confers protection of Her2-positive breast cancer cells to hypoxia: therapeutic implications. Breast Cancer Res, 18, 26.

Breslin S, O'Driscoll L (2016). The relevance of using 3D cell cultures, in addition to $2 \mathrm{D}$ monolayer cultures, when evaluating breast cancer drug sensitivity and resistance. Oncotarget, 7, 45745-56.

Breslin S, O’Driscoll L, O’Driscoll L (2013). Three-dimensional cell culture: the missing link in drug discovery. Drug Discov Today, 18, 240-9.

Calcabrini C, Catanzaro E, Bishayee A, et al. (2017). Marine Sponge natural products with anticancer potential: An Updated Review. Mar Drugs, 15, 310.

Calcul L, Longeon A, al-mourabit A, et al. (2003). Novel alkaloids of the Aaptamine class from an Indonesian Marine Sponge of the Genus Xestospongia. Tetrahedron, 59, 6539-44.

Degterev A, Yuan J (2008). Expansion and evolution of cell death programmes. Nat Rev Mol Cell Biol, 9, 378-90.

Dyshlovoy SA, Fedorov SN, Shubina LK, et al (2014). Aaptamines from the Marine Sponge Aaptos sp . display anticancer activities in human cancer cell lines and modulate AP-1-, NF- B- , and p53-dependent transcriptional activity 
in mouse JB6 Cl41 cells. Biomed Res Int, 2014, 1-7.

Fan F, Tonon G, Bashari MH, et al (2014). Targeting Mcl-1 for multiple myeloma (MM) therapy: Drug-induced generation of Mcl-1 fragment Mcl-1128-350 triggers MM cell death via c-Jun upregulation. Cancer Lett, 343, 286-94.

Fattorusso E, Gerwick WH, Taglialatela-Scafati O (2012). Handbook of marine natural products (E Fattorusso, WH Gerwick, and O Taglialatela-Scafati, Eds.). Springer Netherlands: Dordrecht.

Forouzanfar MH, Afshin A, Alexander LT, et al (2016). Global, regional, and national comparative risk assessment of 79 behavioural, environmental and occupational, and metabolic risks or clusters of risks, 1990-2015: a systematic analysis for the Global Burden of Disease Study 2015. Lancet, 388, 1659-724.

Friedrich J, Seidel C, Ebner R, Kunz-Schughart LA (2009). Spheroid-based drug screen: Considerations and practical approach. Nat Protoc, 4, 309-24.

Gnant M, Harbeck N, Thomssen C (2017). St. Gallen/Vienna 2017: A Brief Summary of the Consensus Discussion about Escalation and De-Escalation of Primary Breast Cancer Treatment. Breast Care, 12, 102-7.

Halanych KM (2004). Invertebrates; Invertebrate Zoology: A functional evolutionary approach. Syst Biol, 53, 662-4.

Hon JDC, Singh B, Sahin A, et al (2016). Breast cancer molecular subtypes: from TNBC to QNBC. Am J Cancer Res, 6, 1864-72.

Hsiao AY, Tung YC, Qu X, et al (2012). 384 hanging drop arrays give excellent $\mathrm{Z}$-factors and allow versatile formation of co-culture spheroids. Biotechnol Bioeng, 109, 1293-1304.

Iqbal N, Iqbal N (2014). Human epidermal growth factor Receptor 2 (HER2) in cancers: Overexpression and Therapeutic Implications. Mol Biol Int, 2014, 1-9.

Kumar V, Abbas AK, Aster JC (2015). Neoplasia. In: Robbins and Cotran Pathologic Basis of Disease, Elsevier health sciences: Philadelphia, pp 306-10.

Larghi EL, Obrist BV., Kaufman TS (2008). A formal total synthesis of the marine alkaloid aaptamine. Tetrahedron, 64, 5236-45.

Lund-Johansen M, Bjerkvig R, Rucklidge GJ (1991). Spheroid Culture in Cancer Research. In: Bjerkvig R (ed) Spheroid Culture in Cancer Research, CRC Press: Boca Raton, pp 10.

Michels J, Johnson PWM, Packham G (2005). Mcl-1. Int J Biochem Cell Biol, 37, 267-71.

Nakamura H, Kobayashi J, Ohizumi Y, Hirata Y (1982). Isolation and structure of aaptamine a novel heteroaromatic substance possessing $\alpha$-blocking activity from the sea sponge Aaptos aaptos. Tetrahedron Lett, 23, 5555-8.

Nakamura H, Kobayashi J, Ohizumi Y, Hirata Y (1987). Aaptamines. Novel benzo[de][1,6]naphthyridines from the Okinawan marine sponge Aaptos aaptos. J Chem Soc Perkin Trans, 1, 173.

Newman DJ, Cragg GM (2004). Marine natural products and related compounds in clinical and advanced preclinical trials. J Nat Prod, 67, 1216-38.

Nieman MT, Prudoff RS, Johnson KR, Wheelock MJ (1999). $\mathrm{N}$-cadherin promotes motility in human breast cancer cells regardless of their E-cadherin expression. $J$ Cell Biol, 147, 631-43.

Nurhayati APD, Prastiwi R, Sukardiman, Wahyuningsih T (2018). Cytotoxic activity of ethanolic extract of the marine sponge Aaptos suberitoides against T47D cell. In: AIP Conference Proceedings, American Institute of Physics Inc. Vol 1945, pp 020013.

Ouyang L, Shi Z, Zhao S, et al (2012). Programmed cell death pathways in cancer: a review of apoptosis, autophagy and programmed necrosis. Cell Prolif, 45, 487-98.
Pires BRB, Mencalha AL, Ferreira GM, et al (2017). NF-kappaB is involved in the regulation of EMT genes in breast cancer cells. PLoS One, 12, 1-20.

Rajivgandhi G, Kumar SN, Ramachandran G, Manoharan N (2019). Marine sponge alkaloid aaptamine enhances the anti-bacterial and anti-cancer activity against ESBL producing Gram negative bacteria and HepG 2 human liver carcinoma cells. Biocatal Agric Biotechnol, 17, 628-37.

Sa'adah NN, Dyah Nurhayati AP, Shovitri M (2017). The anticancer activity of the Marine Sponge Aaptos suberitoides to protein profile of fibrosarcoma Mice (Mus musculus). Iptek J Technol Sci, 27, 53-8.

Sinn HP, Kreipe H (2013). A brief overview of the WHO classification of breast tumors, 4th edition, focusing on issues and updates from the 3rd edition. Breast Care, 8, 149-54.

Smith SM, Lyu YL, Cai L (2014). NF-kB affects proliferation and invasiveness of breast cancer cells by regulating CD44 expression (J Cao, Ed.). PLoS One, 9, e106966.

Van Soest RWM, Boury-Esnault N, Vacelet J, et al (2012). Global diversity of Sponges (Porifera) (JM Roberts, Ed.). PLoS One, 7, e35105.

Thoma CR, Zimmermann M, Agarkova I, et al (2014). 3D cell culture systems modeling tumor growth determinants in cancer target discovery. Adv Drug Deliv Rev, 69-70, 29-41.

Tsukamoto S, Yamanokuchi R, Yoshitomi M, et al (2010). Aaptamine, an alkaloid from the sponge Aaptos suberitoides, functions as a proteasome inhibitor. Bioorg Med Chem Lett, 20, 3341-43.

Ukaji T, Lin Y, Okada S, Umezawa K (2017). Inhibition of MMP2-mediated cellular invasion by NF- $\mathrm{kB}$ inhibitor DHMEQ in 3D culture of breast carcinoma MDA-MB-231 cells: A model for early phase of metastasis. Biochem Biophys Res Commun, 485, 76-81.

Verma S, Miles D, Gianni L, et al (2012). Trastuzumab emtansine for HER2-positive advanced breast cancer. $N$ Engl J Med, 367, 1783-91.

Vijayarathna S, Sasidharan S (2012). Cytotoxicity of methanol extracts of Elaeis guineensis on MCF-7 and Vero cell lines. Asian Pac J Trop Biomed, 2, 826-29.

Vinci M, Gowan S, Boxall F, et al (2012). Advances in establishment and analysis of three-dimensional tumor spheroid-based functional assays for target validation and drug evaluation. BMC Biol, 10, 29.

Vizoso FJ, González LO, Corte MD, et al (2007). Study of matrix metalloproteinases and their inhibitors in breast cancer. $\mathrm{Br}$ J Cancer, 96, 903-11.

Wu Y, Sarkissyan M, Vadgana JV (2016). Epithelial-mesenchymal transition and breast pathology. Ann Pathol, 29, 1-18.

Yousef EM, Tahir MR, St-Pierre Y, Gaboury LA (2014). MMP-9 expression varies according to molecular subtypes of breast cancer. BMC Cancer, 14, 1-12.

Yunovilsa Putra M, Jaswir I (2017). The alkaloids from Indonesian Marine Sponges. Oceanogr Open Access, 2, $1-10$.

This work is licensed under a Creative Commons AttributionNon Commercial 4.0 International License. 